\title{
Sosyal Medyada 'Benliğin Sunumu': Benlik ve Mahremiyetin Sunumunun Bireysel ve Toplumsal Anlamı Üzerine Sosyolojik Bir Değerlendirme
}

\section{'Presentation of Self' in Social Media: A Sociological Evaluation of the Individual and Social Meaning of Presentation of Self and Privacy}

\author{
Dr. Öğr. Üyesi Yaşar SUVEREN ${ }^{10}$, Yüksek Lisans Öğrencisi Ayşe Gül ZEREN KOSAL (D)2
}

$\ddot{O} z$

$\mathrm{Bu}$ çalışma, günümüzde benliğin ve mahremiyetin sosyal medya ve ağlardaki sunumu sorunsalını ele almaktadır. Bunu yaparken Ervin Goffman'ın sunduğu kuramsal ve kavramsal çerçeveden yararlanmaktadır. Bu bağlamda çalışma, günümüzde benliğin ve mahremiyetin sosyal medya ve ağlardaki sunumu ile gerçeklikteki halleri arasında önemli farklılıklar ve gerilimler olduğunu savunmaktadır. Çalışma, sosyal medya platformlarının ve kullanıcılarının benliklerini başkalarına sunma arzusu içinde olduklarını göstermektedir. $\mathrm{Bu}$ arzuyu karşılama doğrultusunda insanlar kendilerini çevrim içi dünyalardaki benlikleri ile 'gerçek dünya'daki benliklerini sunarken sıklıkla manipülatif stratejiler izlemektedirler. İnsanın sosyal davranışlarının ve sosyal ilişkilerinin sonucu olarak, daha geniş toplumsal çevreler tarafindan kabul görme ve takdir edilme ihtiyacından kaynaklanan iyi ve olumlu izlenimler yaratma niyeti, bireylerin benliklerini çevrimiçi ortamda en uygun şekilde sunma taktiklerini kullanmalarına yol açabilmektedir. Sosyal ağlar, bu hedeflere ulaşmak için benlik sunumları için oldukça çeşitlenen seçenekler sunmaktadır. Ancak bu her zaman istenilen sonuçlara ulaşılmasını sağlamamakta ve istenmeyen olumsuz izlenimler edinilmesi gibi sonuçlara yol açabilmektedir. Bu durum hem bireysel hem de toplumsal ilişkilere ve etkileşimlere zarar vererek yanılsamalar üzerine kurulu bir yaşam sürdürülmesine neden olmaktadır.

Anahtar Kelimeler: Benlik sunumu, sosyal medya, sosyal ağlar, izlenim yönetimi, sosyal etkileşim

Makale Türü: Derleme

\begin{abstract}
This study deals with the problem of self-presentation and privacy in social media and networks today. While doing this, it makes use of the theoretical and conceptual framework presented by Erving Goffman. In this context, the study argues important differences and tensions between self-presentation in social media and networks and reality. The study shows that social media platforms and their users have a desire to present their selves to others. To satisfy this desire, people often use manipulative strategies when presenting their selves online. As a normal characteristic of people, the intention to create good and positive impressions stemming from the need to be accepted and appreciated by the wider social circles leads individuals to use the tactics of presenting themselves most appropriately manners in online platforms. Social media and social networks offer a wide variety of options for self-presentations to achieve these goals. However, this does not always provide the desired results and may lead to undesired negative impressions. This situation harms both individual and social relations and interactions, leading to a life based on illusions.
\end{abstract}

Keywords: Self presentation, social media, social networks, impression management, social interaction

${ }^{1}$ Sakarya Üniversitesi, Fen Edebiyat Fakültesi, Sosyoloji Bölümü, ysuveren@ @akarya.edu.tr

${ }^{2}$ Sakarya Üniversitesi, Sosyal Bilimler Enstitüsü, İletişim Bilimleri, ayse.kosal@ ogr.sakarya.edu.tr

Atıf için (to cite): Suveren, Y., \& Zeren Kosal, A. G. (2021). Sosyal medyada 'benliğin sunumu': Benlik ve mahremiyetin sunumunun bireysel ve toplumsal anlamı üzerine sosyolojik bir değerlendirme. Afyon Kocatepe Üniversitesi Sosyal Bilimler Dergisi, 23(4), 1226-1241. 
Paper Type: Review

\section{Giriş}

Günümüzde sosyal medya, benliğin stratejik sunumu için tüm yaş gruplarındaki insanlara sınırsız firsatlar sunuyor gibi görünmektedir. Son bulgular, sosyal medya kullanıcılarının benliklerini sunma ve izlenim oluşturma hedeflerine ulaşmak için çok çeşitli stratejiler ve taktikler güdebileceğini ve bu sunumların izleyiciler tarafından algılanma şeklini kayda değer bir biçimde etkileyebileceğini göstermektedir (Heston ve Birnholtz, 2016). Erving Goffman'ın (1959; 2009) kuramlaştırmasına göre, bireylerin arzu edilen belirli yönlerini vurguladıkları ve istenmeyen yönlerini küçümsedikleri veya görmezden gelmeye eğilimli oldukları için benliklerini seçmeci bir biçimde sundukları yaygın olarak kabul edilmektedir. Pratik olarak, benlik sunumuna hedef odaklı olarak bakılabilir, çünkü benlik sunumu genellikle izleyiciler için bir performanstır. Bu nedenle de başarılı bir benlik sunumu, izleyicilerin söz konusu performansı kabul etme düzeyleri tarafindan belirlenir. Goffman başta olmak üzere (2009), Leary ve Kowalski (1990) ve Schlenker'inki gibi (1985) erken benlik sunumu kuramları, bağlam ve izleyicinin belirgin ve sınırlı olduğu yüz yüze performanslara ve benlik betimlemelerine odaklanmıştır. Ancak dünya o zamanlardan günümüze modern benlik kuramları, geleneksel kuramların yeniden gözden geçirilmesine neden olan, özellikle de elektronik medya bağlamında kayda değer teknolojik bir dizi gelişmelerden geçti. Söz konusu bu gelişmeler, sosyal medyada ve gerçeklikte mahremiyet ve benliğin sunumu arasındaki artan farklılıkları, gerilimleri dikkate almak durumunda kaldı. Bu nedenle, ilgili kuramlar mevcut sosyal medya icatlarından önce oluşturulmuş olsa da, günümüzde sosyal medya, benlik sunumunu açıklamada ve anlamakta bir zemin oluşturmaya ve önem taşımaya devam etmektedirler.

Daha da önemlisi, internetin kitlesel kullanımı, benlik sunumu için kapsamlı ve heyecan verici platformlar haline geldi. Çok kullanıcılı sohbet odaları, kişiselleştirilmiş web siteleri ile ilgili bir literatür oluşmuş ve bu ortamlardaki benlik sunumları kuramsallaştırılmıştır (DeVito, Birnholtz ve Hancock, 2017, s. 743; Evans, Pearce, Vitak ve Treem, 2017, s. 40). Konu hakkındaki literatüre bakıldığında, çevrimiçi iletişimin, bu ortamlardaki ilişkili anonimlik düzeyleri nedeniyle çoğunlukla özgürlükle ilişkilendirildiği görülmektedir. Ancak, bu görüş ya da yaklaşım, 21. yüzyılda sosyal medyanın oluşumunun ve yaygınlaşmasının, sosyal ağ sitelerinin kullanımı ve özelliği aracılığıyla benlik sunumu oyununda devrim yarattığını öne süren Anderson ve Jiang (2018) tarafından sorgulanmıştır. Azaltılmış-edilgen izleyici katkısı, kullanıcıların anonimliği ve kolektif bağlamın kayboluşu ve çöküşü, soyal medyada benlik sunumunu biçimlendirmektedir. Örneğin, kullanıcı kimliğini temsil etmek için çevrimiçi oyunlarda olduğu gibi avatarlar ve takma adlar kullanmak yerine, Facebook gibi platformlar, kullanıcıları sürekli olarak durum ve profil resmi güncellemeleri yapmaya ve gerçek adlarını belirtmelerini sağlamaya teşvik ederek çevrimiçi anonimliği azalttı (Facebook, 2020). Ayrıca, Anderson ve Jiang (2018), Facebook, Instagram, Twitter ve WhatsApp gibi sosyal medya platformlarının, insanların medya arkadaş listelerinde birçok çevrimdışı aile üyesi, ahbap, akraba ve meslektaş içerdiğini ve bunun da anonimlik olasılığını daha da azalttığını vurgulamaktadır. $\mathrm{Bu}$ seyreltilmiş/azaltılmış anonimlik, daha önce çevrimiçi anonimliğin sağladığı 'imkânlar' nedeniyle iletişim özgürlügüne atfedilen gizlilik ve benliği ifade etme sorunlarına davetiye çıkarmaktadır. Söz konusu bu mevcut halde, sosyal medya platformlarının sunduğu sınırlı kontrol nedeniyle benlik sunumu ve mahremiyet ile ilgili bir dizi sorunun ortaya çıktığı söylenebilir. Kullanıcılar, başkalarının izlenimlerine katkıda bulunma veya bunları değiştirme konusunda çeşitli sınırlılıklara sahip görünmektedirler. Fakat öte yandan sosyal medya araçları, diğer insanların etiketleme, beğenme, paylaşma ve yorum yapma gibi kişinin benlik sunumunu etkileyebilecek içerik ekleme ve bunlara katkıda bulunma firsatlarını da genişletti (Choi ve Sung, 2018, s. 2291). Ayrıca, sosyal medyanın artan kullanımı insanları çok geniş bir bilgi ve çeşitli türden sosyal medya izleyicileriyle karşı karşıya bıraktığından, bireylerin benlik sunumlarını da haliyle etkilemektedir. Hollenbaugh'a göre (2019) izleyicilerin 
görünmezliği, benliklerini seçici bir biçimde temsil etmeyi zorlaştırırken, aynı zamanda kullanıcıları herhangi bir benlik sunumu zorluklarını aşmak için uygun stratejiler bulma konusunda ise yaratıcı hale getirmektedir. $\mathrm{Bu}$ arka plan üzerine, bu çalışma, günümüzde benliğin ve mahremiyetin sosyal medyada sunumu ile gerçeklik arasında önemli bir farklılık ve gerilim olduğu iddiasını savunmaktadır. Bu durum hem bireysel hem de toplumsal ilişkilere ve etkileşimlere zarar vererek yanılsamalar üzerine kurulu bir yaşam sürdürülmesine neden olmaktadir.

\section{Benliğin Sunumu}

Goffman (2009), kişinin kendini başkalarına kabul edilebilir biçimlerde sunması gerektiğinin kuramlaştırılmasında öncü isimlerdendir. Onun dramaturjik yönteminde, bireylerin benliğin temel bir motivasyon çekirdeğine sahip bir oyuncu olduğu ve izlenimlerini stratejik olarak yönettiği bir teatral performans kullandığg savlanır. Bu yaklaşımda, insanlar kendilerini temsil ettiklerini hissettikleri ve başkalarının onları görmesini istedikleri biçimlerde sunarlar. $\mathrm{Bu}$ düşünce, benlik sunumunun izlenim yönetimini (management of impression) içerdiğine işaret eder, çünkü bireylerin doğal olarak başkaları ve toplum tarafından bireysel ve toplumsal etkileşim ve ilişkilere dahil edilmeleri ve kabul edilmeleri gerekir ki bu da onların eylemlerini yönlendirir. Böylece bireyler, performans hedeflerini gerçekleştirmenin bir yolu olarak, belirli bağlamlarda belirli izleyiciler için (çevrimiçi ve çevrimdışı) davranışlarını biçimlendirirler. Açıkçası, kişilerin 'benlikleri' kafalarının içi değil, rol performansları veya davranışları gözlemlenerek görülebilir. Goffman'ın dramaturjik yöntemi, bireyleri sahnede bir oyuncu perspektifinden ele almıştır. Bu yaklaşımda, insanların kendilerini diğer insanlarca görülmeyi veya algılanmayı umdukları biçimlerde sunmak için izlenim yönetimini kullandıklarına inanılmaktadır (Bullingham ve Vasconcelos, 2013). Bu yaklaşıma göre her durum, mevcut/izleyen kişilere bağlı olarak bireylerin çeşitli roller üstlendiği bir oyun sahnesidir. Sınıf arkadaşlarıyla, iş arkadaşlarıyla, ebeveynlerle, arkadaşlarla, yabancılarla veya günlük yaşamda herhangi bir buluşmadayken nasıl davranılacağını hayal edelim. Kesine yakın bir biçimde, hem bilinçli hem de bilinçsiz olarak bu etkileşim süreçlerinde kişilik, kimlik ve benlik değiştirilir. Etkileşime girilen söz konusu bu gruplar 'sizin' birçok yönünüzü görürler. Bu durumda, benlik sunumu her zaman izleyiciye bağlıdır, çünkü bunların değişen beklentileri vardır. Benzer biçimde, sunum yapan kişi de, etkileşime girdiği insanlara göre benliğinin en uygun yönlerini gösterir. Sosyal ağ sitelerinin kullanımıyla ilgili kültürleri karşılaştıran araştırmalar, Batı'nın kendini tanıtma kültürü nedeniyle benliğin sunumu ve ifşa edilmesi üzerinde zorlayıcı etkilerin olduğunu göstermiştir (Omori, 2014). Stuart Hall'un İngiltere'nin otoriter popülist kültürüyle ilgili teorik çıkarımı, İngiliz çocukların, ergenlerin ve yetişkinlerin benliğin "popülist" sunumundan keyif aldıkları yönündedir (Morelock ve Narita, 2018, s. 139). Bu nedenle İngilizler, kendilerini hedef kitlelerine sunarlarken diğer kültürlerden daha fazla etkinlik göstermektedirler. Bangladeş'le ilgili bir kültürel çalışmada, çoğu Hijras ${ }^{3}$, çevrimiçi tacizin üstesinden gelebilmek için hedef kitlelerine yönelik olarak kendi kararlarını verme ve benlik sunumlarını cerrahi müdahaleler de dahil bilinçli olarak oluşturmaya devam etmektedirler. Amerikalılar ise benlik sunumlarını sosyal statülerini geliştirecek biçimde gerçekleştirmektedirler (Nova, DeVito, Saha, Rashid, Roy Tunzo, Afrin ve Guha, 2021). Türkiye'de ise sosyal medya/çevirimiçi kullanıcılarının benlik sunumu, takipçileri ile etkileşimi (beğenme, takip etme, yorum yapma, paylaşma, ilgisiz kalma, eleştirme vb.) ve bu etkileşimin hızı ile doğru orantılı olarak gerçekleşmektedir (Gulmammadzada ve Işıklı, 2020). Bu doğrultuda Türkiye'de benlik sunumunun beğeni odakl1, ideal yaşam algisı çerçevesinde gerçekleşmekte olduğunu söylemek mümkündür.

Benliğin kültür bağlamında sunumu belirli bir dikkat ve özeni gerektirmektedir. Hassas fotoğraf ve resimler, bilgi paylaşımı, arkadaş olunan kişi sayısı ve çeşitli faktörler sosyal platform etkinlik düzeylerini etkilemektedir. Bu bakımdan akademik çalışmalar sürekli olarak

\footnotetext{
${ }^{3}$ Güney Asya'da transgender ('üçüncü cins’) olarak görülen, kabul edilen insanlar.
} 
benliği sunmanın ve izlenimi yönetmenin analizi ve anlaşılması bakımından Goffman'ın önerdiği dramaturjik modeline göndermede bulunmaktadırlar. Bu model, bireylerin genellikle izleyici bölgelerinin sahne arkasını ve muhtemelen tehdit edici izleyici bölgelerinin de sahne önü performansını 'kotarmak' için kendilerini farklı biçimlerde temsil etmeyi tercih ettiklerini varsaymaktadır (Nova vd., 2021, s. 8). Yapılan araştırmalar göstermektedir ki, sosyal medya kullanıcıları içeriklerini oluştururken kamera açısını ayarlamak, deneme çekimi yapmak gibi ön hazırlık aşamalarını tamamladıktan sonra, içeriklerinin ses veya görüntü kalitesinin artırılması, çıkartmaların eklenmesi gibi prodüksiyon çalışmaları ile hazırladıklanı içeriklerin niteliğini artıracaklarını düşünmektedirler (Gül Ünlü, Kuş ve Göksu, 2020). Bu durumda, benlik sunumu tamamen bağlama bağlıdır ve kişilerin (icracıların) ön aşama olacak davranışı, kimliği veya temsilleri belirli bir 'özen ve dikkatle' seçmesini gerektirmektedir.

Benlik sunumu birçok biçimde ve çeşitli yöntemlerle gerçekleşir. Jones ve Pittman'ın (1982) belirttiği gibi, insanlar arzu edilen davranışı göstermek için övme, kendini yüceltme, yıldırma, yalvarma ve örnek alma gibi çeşitli taktikler kullanırlar. Yeni iletişim teknolojileri sağladığı olanaklarla, benlik sunumu ve izlenimleri yönetme seçeneklerini olağanüstü çeşitlendirmiştir. İnternet çağında insanlar çevrimiçi izlenimlere uygun ayrıntıları seçerek kendilerini inşa edebilirler veya yeniden kurgulayabilirler. Örneğin günümüz gençleri, sosyal medyayı çok farklı biçimlerde kullanarak kendileri için kurguladıkları benliklerini sunmakta ve başkalarının izlenimlerini de yönetmektedirler (Anderson ve Jiang, 2018). Buna göre, çevrimiçi izlenim yönetimi, kullanıcılara daha yüksek düzeyde özgürlük sunan sosyal medya görsel anonimliğini içerir. $\mathrm{Bu}$, kullanıcıların kendilerini arkadaş canlısı, esprili, modaya uygun, güzel ve sevimli olarak tasvir etmek için farklı çevrimiçi özellikleri özgürlük ve izlenim yönetimi firsatlarıyla manipüle ettikleri anlamına gelir (Harris ve Bardey, 2019). Ancak Harris ve Bardey (2019), Goffman'ın yaklaşımının, çevrimiçi sunumların genellikle kişinin günlük yaşamdaki davranışını veya doğasını aşan nitelikler gösterdiğine dair kuramıyla örtüşen bir ikilemi de vurgulamaktadır. Buna göre, iletişim teknolojilerindeki gelişmeler, insanların kendilerini izleyicilere kendilerinin uygun gördükleri biçimlerde sunma seçeneklerini de çeşitlendirmiş ve genişletmiştir.

Alvarez ve Hua Chen (2021), çevrimiçi benlik sunumuyla ilgili önceki çalışmaların, bloglar, sosyal ağlar, flört uygulamaları veya web siteleri gibi asenkron iletişim ortamlarını incelemeye odaklandığına işaret etmektedir. Başka araştırmalar ise, sohbet odaları, mesaj panoları ve gerçek bireysel resimler ve bilgiler yerine avatarlar ve takma adların o kişiyi başkalarına sunduğu, sohbet odaları, mesaj panoları ve çok oyunculu çevrimiçi oyunlar gibi bir dereceye kadar anonimlik içeren platformlarda benlik sunum biçimlerine odaklanmıştır (TsayVogel, Shanahan ve Signorielli, 2018, s. 144). Odaklandıkları ve ele aldıkları çerçeveler farkl1lık gösterse de araştırmalar, benlik sunumunun anonim çevrimiçi kanallarda daha gerçek ve eğlenceli olduğunu, anonimlik olmadan veya sınırlı anonimliğin ise daha az gerçek olduğu konusunda hemfikirdirler. Bu, Goffman'ın dramaturjik yaklaşımına göre izleyicilerin olumsuz tepkilerden ve izlenme tehdidinden kaçınmak için insanların sahne önünde birer oyuncu gibi davrandığı fikrinin konuya yönelik bağlantı düzeyine ve açıklama gücüne işaret etmektedir. Gerçekten de, bireylerin çeşitli mecralardaki canlı performanslarında izleyicilerle etkileşim anında gerçekleşir ve oyuncunun gerçek yüzü ve kimliği aşikar hale gelir. Bu da daha az anonim sosyal medya ortamlarında benlik sunumunu anlamak için karşılaştırmalı bir bağlam sunar.

\section{2. Çevrimiçi Benlik Sunumunu Belirleyen ve Etkileyen Faktörler}

Benlik sunumu için çevrimiçi platformların kullanımı 21. yüzyılda, özellikle gençler ve yaşlılar arasında yaygınlık kazandı. Sosyalleşme ve kültür üzerine literatür, insanların benliklerini sunum için çevrimiçi yolları kullanmayı tercih etmelerinin birçok nedenine büyük ölçüde işaret etmiştir. 
Sosyal medyanın kullanımını anlamaya çalışan başlıca modellerden biri olan Goffman'ın benlik sunumu perspektifi, çevrimiçi benlik sunumunun arkasındaki ana faktörün, sosyal medyanın bu yolların ana hedefi olduğunu göstermektedir (Seo, Lee, Bhang ve Lee, 2021, s. 244). Bu kuramlaştırmaya göre, bireysel benlik sunumunun gündelik yaşamdaki kişilerarası etkileşimler izlenerek anlaşılabileceği öne sürülmektedir. Bu nedenle, çeşitli araştırmacılar ve incelemeler, bu kuramın bilgisayar aracılı iletişim ve etkileşimlerle de ilgili olduğunu kabul etmektedir. Jo, Yim, Lee, Choi ve Baek (2017, s. 513) ergenlerin yeni oluşturulan sosyal medya platformlarının özelliklerini, varlıklarını ve tercih ettikleri davranışları başkalarına sunmak için kullandıklarını gözlemlemiştir. Bu, kişilerarası etkileşimleri analiz etmek ve gözlemlemek için mevcut tekniklerin Goffman'ın zamanından farklı olmasına rağmen, söz konusu kuramın, benliğin çevrimiçi sunumunun anlaşılmasında neden tercih edildiğini anlamak için elverişli bir temel sunduğu anlamına gelir.

Sosyal medyanın benliği sunmada kullanımını belirleyen bir diğer faktör de sosyal medya araçlarının sorunsuz kullanımıyla ilgilidir. Seo, Lee, Bhang ve Lee (2021), problemli internet kullanımına ilişkin ergenlerin stress belirleyicileri üzerine bir deney yapmıştır. Araştırmada, benlik sunumu için çevrimiçi kullanımının arkasındaki itici güçler olarak açılanabilecek şeyleri buldular. Bu deneyde kontrol grubu, sosyal medyada kendilerini normal yaşamlarında olduğundan daha havalı, daha iyi ve daha sevgi dolu olarak tanitmaya çalışmışlardır. Gerçek yaşamlarında internet kullanım sorunu olmayan bu ergenler, benliğin kurgusal, düzenlenmiş ve geliştirilmiş hallerini başkalarıyla paylaşmaya daha istekli oldular. Öte yandan, fiziksel, zihinsel sağl1k sorunları, kardeşlerle olan meseleler ve arkadaşlarla rekabet gibi sorunları olanlar, muhtemel tehdit edici olumsuz tepkilerden korktukları ve çekindikleri için kendilerini çevrimiçi ortamda sunmaya daha az eğilimli olmuşlardır. Bu bulgular, internet kullanımıyla ilgili herhangi bir sorun yaşamamanın, insanların kendilerini tanıtmak için çevrimiçi arenayı başka yerlerde olduğundan daha fazla kullanmaya yatkınlıklarının önemli bir belirleyici faktör olduğunu gösteren önceki çalışma sonuçlarından farklı değildir (DeVito vd., 2017, s. 747; Evans vd., 2017, s. 41). Heteroseksüel ilişkileri olmayan ve 'iyi-güzel-yakışıklı' bir görünüme sahip olmayan ergenler ise, başkalarının ilgisini çekmek için hiçbir şansları olmadıklarını veya sınırlı bir ilgiye maruz kalacaklarından emin oldukları için çevrimiçi yolları kullanmaya daha fazla eğilimlidirler (Nova vd., 2021, s. 22). Bu nedenle, bu araştırmanın kanıtları, insanların kendilerini gerçek dünyadaki halleriyle sunmaktansa kendilerini daha iyi hissettikleri hayali/kurgusal halleriyle sunmanın onları daha iyi hissettirdiğini vurgulamaktadır. Ayrıca, kimlik inşası fikri, sanal benlik sunumu için bir itici güç olarak tanımlanmıştır. Araştırma, sanal dünyadaki aktörlerin kendilerine özgü kimliklerini neden inşa ettikleri sorusunu ele almaktadır. Jande, Ibrahim, Bahru ve Aireen (2020, s. 112), sanal dünyanın insanlara fiziksel/gündelik yaşamda elde edilmesi oldukça zor olan bir benlik çeşitlemesi yaratma imkânı verdiğini gözlemlemiştir; bu durum, aktörün kimliğinin bir uzantısını yaratmaktadır. Bununla birlikte, dijital kimlik seçenekleri, sanal benlik sunumu ve avatarları alarak aktarımdan daha fazlasıdır. Örneğin, bir avatarın nitelikleri, gerçek fiziksel formda ancak ek özellikler kullanan oyuncuya kısmen benzer. Böylelikle bir oyuncu, gerçek hayatta sahip olmadığı diğer nitelikleri sergileme şansı elde eder. Psiko-pedagojik bakış açısından bakıldığında, dijital kimlik geliştirmek, benliğin, başkalarının ve dijital kültür müzakeresinin toplumsal ve bireysel yansıması anlamına da gelir (Muñoz-Rodríguez, Hernandez-Serrano ve Tabernero, 2020). Bu görüşe göre, bir kimlik oluşturmak, kişinin kendini uygun hissettiği kişilikte sunmasına yardımcı olan çevrimiçi yetenekler ve özellikler tarafından sağlanır. Sanal temsil kuramına göre: "artzamanlılığa ek olarak eşzamanlılık vardır, çünkü yaşlı yetişkinler diyalektik süreci duygular, tercih edilen veya kaçınılan yerlerle yüklü artzamanlı izler olarak yansitabilirler" (Muñoz-Rodríguez vd., 2020, s. 13-15). Bu kuramsallaştırmaya göre, yetişkinler kendilerini rahat hissettikleri çevrimiçi sitelere sik sık uğramaktadırlar, çünkü buralar bir tür sosyal gelişim platformudurlar ve buralarda yaşama duygusunu hissedebilmektedirler. $\mathrm{Bu}$, tercih edilen sosyal alanda yarattıkları ve sürdürdükleri güvenli kimlik tarafından aidiyet duygularının güçlendiğine işaret eder. Bu görüşler nihayetinde benliği sunum için çevrimiçi 
platformları kullanmanın aynı zamanda rahat bir sosyalleşme alanı bulma duygusu ve arzusu tarafından belirlendiğini göstermektedir.

Günümüzün modern toplumlarında insanların ilişkiler, etkileşimler yaratması, sürdürmesi ve mümkün olduğu kadar çok sosyal destek toplaması gerektiği söylenebilir. Pratik olarak bu, birinin kendilerini çevrimiçi olarak tanıtıp tanıtmayacağını belirleyen ana faktörlerden biri sayılabilir. Chen (2019), günümüzde sosyal ă̆ sitelerinin, sosyal medya platformlarının ve anlık mesajlaşma uygulamalarının ilişkiler kurmak ve sürdürmek ve sosyal sermaye toplamak için kolaylaştırıcı araç ve mecralar olduğunu öne sürmektedir. İnsanların somut ilişkilere ve bağlantılara sahip olmayı arzulaması, onları, kendilerini arzu ettikleri ilişki ve insanları cezbedecek biçimlerde sunmak için çevrimiçi sitelere ve uygulamalara büyük bir hevesle bakmaya sevk eder. $\mathrm{Bu}$ fikrin literatürde destek gördüğ̈̈ göz önünde bulundurulduğunda, sosyal medya ve diğer çevrimiçi platformların bu ihtiyacı karşıladıkları için kullanıldığı sonucuna varılabilir. Genel olarak, çevrimiçi özellikler, istenen ilişkileri kurmak ve sürdürmek için gerekli olan yoğun izlenim yönetimi ve benliğin sunum etkinliklerine izin verir. Ancak, izlenim yönetimi tasvirlerindeki farklılıkların, belirli izleyicileri gerçek hayattaki insanların sunumlarıyla örtüşüp örtüşmediği konusunda cevaplanmayı bekleyen sorular ve tartışmalar bulunmaktadır. Bu soruya verilen bazı cevaplar, benliğin medyadaki ve gerçek hayattaki mevcut temsilinde bariz bir fark olduğunu ortaya koymaktadır.

\section{Benlik Sunumunda İzlenim}

İnsanların kendilerini tanıtmak için çevrimiçi platformları kullanmak istemelerinin ana nedenlerinden biri, başkaları için uygun bir izlenim yaratma arzusudur. Reinikainen, Tan, Luoma-aho ve Salo'ya göre (2021), insanlar özellikle ilişkiler kurmayı ve derinleştirmeyi umarak, kendileri hakkında bireysel bilgileri başkalarına açıkladıklarında, benlik sunumunda bir izlenim oluştururlar. Çeşitli medya teknolojileri, insanlara benliklerini sunum seçenekleri sağlayarak izlenimleri yönetme firsatları vermektedir. İnternet kuşağında, insanlar çevrimiçi izlenimlerine uygun belirli ayrıntıları seçebilirler. Örneğin, gençler bireysel niteliklerinin yanı sira fotoğraflar, görseller, metinler, durum güncellemeleri, yorum ve etiketlemeler kullanarak kendi oluşturdukları izlenimlerini yönetirler (Anderson ve Jiang, 2018, s. 28). Böylelikle medya teknolojilerinin sunduğu olanaklar aracılığıyla istenen izlenimleri de elde edebilirler.

İnsanların sosyal varlıklar olarak doğuştan gelen yapıları gereği, kişinin kendi benlik duygusunu sunma ve içselleştirme yeteneği, ancak etkileşimlerde bulunduğunda kendini dişa vurabilir. $\mathrm{Bu}$ durumda izlenim yönetimi, bireylerin deneyimlediği toplumsallığın gerekli bir öğesi haline gelir. İzlenim yönetimi gerekli olsa da, Ezzat (2020), ağ bağlantılı etkileşim ve iletişim araçlarının karmaşık yapısının, izlenimleri yönetmeyi de bir ihtiyaca dönüştürdüğüne dikkat çeker. Goffman, dramaturjik yaklaşımında, bir yandan bireylerin izleyicilerin (diğerlerinin) önüne çıktıkça, performans yoluyla başkalarına verilen izlenimi de kontrol etmeye çalıştıklarını açıklar. Bu durumda, bir birey sosyal sözleşmeleri ve kuralları yerinde gözlemler. Öte yandan, izleyiciler veya diğerleri, kendi taraflarından doğrudan veya dolaylı ipuçlarını kullanarak performans sergileyen birey/aktör hakkında bilgi toplamaya çalışırlar (Bullingham ve Vasconcelos, 2013, s. 105).

Etkileşimlerde izlenim yönetimi, istenmeyen izlenim sonuçları doğurma olasıllğ nedeniyle büyük öneme sahiptir. Goffman tarafından önerilen performansa dayalı yaklaşım, bir izleyiciye bir izlenim sunarken, diğer istemsiz izlenimlerin de izleyicilere ulaşabileceğini ortaya koymuştur (Serpa ve Ferreira, 2018). Kişiler kendilerini başkalarına sunarken, icracının benlik sunumu hakkında olumsuz ve kabul edilemez ipuçları bulabilirler. Bu gibi durumlarda, izlenimi yönetmek karmaşık bir süreç haline gelir, çünkü bazı durumlarda, başkaları tarafından olumsuz bir benlik izlenimi edinildiğinden istenen sonuçlar da elde edilmez. Gül Ünlü ve arkadaşları (2020) sosyal medya uygulaması olan TikTok kullanıcıları ile yaptıkları çalışmada, kullanıcıların kişisel bilgilerinin yanı sıra, ortaya koymak istedikleri izlenimlerine uygun olmadığını düşündükleri içerikleri daha fazla etkileşim alacak olsalar bile paylaşmaktan 
kaçındıkları, ortaya koymak istedikleri izlenimlerine uygun olduğunu düşündükleri içerikler arasından tercih yaparken ise alacakları etkileşim oranını dikkate aldıkları sonucuna varmıştır. Bilgiyi sunmadan önce izleyicileri anlamak, özellikle çevrimiçi izleyicilere kendini sunmada temel bir öge olarak tanımlanmıştır (Ezzat, 2020). Buradaki düşünce, çevrimiçi etkileşim platformlarının, özellikle sosyal medyanın, bireylerin bilgilerini kişiler, arkadaşlar veya daha fazlası şeklinde görüntüleyen gizli izleyicilere de sahip olabilmesidir. İzleyicilerin farklı kuşaklardan insanlardan oluştuğu ve bunların da değişen çevrimiçi kültürlere uyum sağlayabildikleri düşünülürse benlik sunumu, istenmeyen izlenimlerin ortaya çıkmasına neden olabilir. Bu yüzden, izlenim yönetiminin kendisi giderek sosyal medyada benliği sunmanın önemli bir parçası haline gelmiştir.

Kimlik ve izlenim, benlik sunumunun ayrılmaz yönlerini oluşturmaktadır. Santoso, Nombrado, De Guzman, Yumul ve Mariano (2021), Goffman'1n klasik izlenim yönetimi kuramının bugün hâlâ geçerli olmasının nedenini, bireylerin çevrimiçi olarak nasıl pazarlık yaptıklarına ve kimliklerini nasıl inşa ettiklerine dair önemli bilgiler veriyor olmasıyla ilişkilendirmektedir. Farklı bilim insanları ve araştırmacılar söz konusu kuramı, bireylerin kimliklerinin çevrimiçi ve çevrimdışı ortamlarda nasıl yerleşik olduğunu kavramsal olarak açıklamak için kullandılar. Goffman Gündelik Yaşamda Benliğin Sunumu başlıklı çı̆̆ır açan çalışmasında, "bir birey diğer insanlarla temas kurduğunda, bu birey başkalarının kendisinde bırakabileceği izlenimi değiştirerek veya sabitleyerek kontrol etmeye veya yönlendirmeye çalışacaktır" fikrini ortaya koymuştur (Beames, Burke ve Steele, 2021, s. 82). Bu açıklamaya göre, izleyici(ler) değiştiğinde kişinin davranışını veya görünümünü düzenleme ihtiyacı da kaçınılmaz hale gelmektedir. Bu nedenle, kişi farklı izleyiciler üzerinde bir izlenim bırakmak istediğinde kişinin kimliği bükülür, bu da sosyal medyada benlik inşa etmenin neden eğlenceli olabileceğini açıklar. Sosyal medya, arzu edilen izlenim ve temsilleri farklı hedef kitlelere sunmak için oldukça çeşitlenen seçenekler sunmaktadır.

\section{Sosyal Medyada Benlik Sunumu ve Mahremiyet}

Sosyal medya platformlanı ve diğer ağ siteleri, kullanıcıların çeşitli güncellemeleri paylaştığı ve arkadaşlarıyla iletişim kurduğu popüler internet alanlarına dönüşmüştür. $\mathrm{Bu}$ dönüşüm, insanları birbirine yaklaştırarak ve halihazırda var olan ilişkileri sürdürüp yeniden üreterek sosyal sermayenin inşasına yardımcı olan son derece kolaylaştırılmış bilgi alışverişine neden oldu (Yang, Cao ve Liao, 2018). Bu, sosyal medya platformları için doğru olsa da, Hearn (2017), kullanıcılar için medya kaynaklı mahremiyet sorunlarının sosyal ağ sitelerinin sürdürülebilirliğini yok edebileceğini ve hatta bu sitelerin kamusal değerini mahvedebileceğini belirtiyor.

İster çevrimdışı ister çevrim içi olsun, herhangi bir iletişim sürecinde, bireyler kimliklerini diğer insanlarla (sembolik) etkileşim süreçleri içinde ve bu süreçlerle bağlantı kurarak gerçekleştirirler. Buna karşılık, aynı zamanda iletişimsel tepkiler yoluyla kendi kimliklerini de ortaya koyarlar. Sa, Serpa, Ferreira ve Santos (2020) kimliği, yalnızca iletişimsel olarak bir başkasına yansıtma yoluyla sağlanan, kişinin kendi içindeki bireyselliğin yansıması olarak tanımlarlar. Bu yaklaşıma göre, sosyal medya platformları etkileşim için bir arenadır, ancak sosyal ilişkilerin ortadan kaldırılması gibi, bazı kötü niyetli veya olumsuz etkileşimlerle de sonuçlanabilir. Örneğin, çevrimiçi olarak yayınlanan, dolaşıma giren bazı bilgiler üzerindeki bir tartışma, alıcılar veya izleyiciler tarafından ciddi manipülasyon, taciz veya başkaca kötü muamele biçimleriyle sonuçlanabilir. Bu arada, böyle bir karışıklık içinde gerçek bilgiyi ve bilgilenmeyi savunan birileri söz konusu mecralarda olabilir, yeni ilişkiler kurulabilir ve giderek sürekli iletişim ve arkadaşlıklara da yol açabilir. Öyle veya böyle bu olasılıkların arka planındaki sorun, sosyal medyanın benlik sunumundaki mahremiyet meselesinde yatmaktadır.

İnsanların kendilerini ve benliklerini başkalarına sunma şeklini büyük ölçüde değiştiren internet açısından, Yang ve arkadaşları (2018), sosyal medyanın farklı kanallarının hem iyi ve olumlu bir değişiklik hem de insanların birbirleriyle etkileşim yolları sağlaması yönünden bir 
meydan okuma olduğunu savundular. Yaptıkları çalışmaya göre, diğer sosyal ağlar gibi örneğin, Facebook'un da, daha geniş bir kitle tabanıyla bağlantı kurmaya yardımcı olmak için özel bilgilerin birçok biçimde sunulmasına olanak sağladığını vurgulamaktadırlar. Sosyal medya siteleri, benliği sunmak ve bunu başkalarına sunarken benliği yönetmek için de çeşitli olanaklar sunar. Ancak yine de Yang ve arkadaşları (2018), diğer insanlar bu bilgilere kendilerine uygun biçimlerde erişip bunları kullandığında Facebook'un bir dizi zorluklara neden olduğunu iddia ediyorlar. Sá ve arkadaşlarına göreyse (2020, s. 13), çevrimiçi geri bildirimin etkisi, kamusal, yarı kamusal ve kalıcı görünürlükleri nedeniyle yüz yüze geri bildirime kıyasla daha derindir. Bireyler arası çevrimdışı ve çevrimiçi ilişkilerin önemli bir parçası olarak, benlik sunumu çevrimiçi ve daha geleneksel (yüz yüze) ortamlarda son derece farklı biçimlerde gerçekleşir. Özellikle insanların dijital medya etkinliklerine katılımı, bireysel mahrem bilgileri ve sorunları ifşa etmek de dahil olmak üzere benliğin sürekli bir biçimde sunuluşu anlamına da gelmektedir. Geçmişte internet teknolojilerine temkinli yaklaşılmış olsa da gelinen noktada sosyal medya uygulamaları kullanıcı tercihlerini sisteme aktaran yeni bir kimlik inşasına sebep olurken sosyal ağlarda paylaşılan bilgilerin bizzat kişiler tarafından bu ortamlara taşınıyor olması verilerin genele ait olmasını doğurmaktadır (Yıldız, 2021). Bu durumda mahremiyet algısında bir dönüşüm yaşandığını söylemek mümkün olacaktır. Aslında, mahrem konuların açıklanması, çevrimiçi bireyler arası ilişkilerin önemli bir bileşeni olarak kabul edilir. Bu nedenle, aktörler kendilerini sosyal medyada sunarlarken, çevrimiçi etkileşimlerde ilişki kurmanın bir özelliği olan bireysel mahremiyet sorunlarını paylaşmaktan veya sergilemekten de kaçınamaktadırlar.

İlgili literatür tutarlı bir biçimde dijital medyanın bireylere kendilerini çevrimiçi ortamlarda sözlü ve sözsüz olarak göstermeleri için çeşitlenen birçok araç sağladığını göstermektedir. Solmaz (2017), çevrimiçi sosyal ağ platformlarının benlik sunumu için derin bir kanal olarak bireylerin benliklerini sunma konusunda oldukça motive olduklarını, diğerlerinin ise onu bir izlenim yönetimi aracı olarak kullandığını gözlemlemiştir. Sosyal medya aktörleri, kimliklerinin belirli yönlerini en aza indirgeyerek veya vurgulayarak yaratılan izlenimlerini ustalıkla yönetebilmektedirler. Örneğin, Franchina ve Lo Coco (2018), beden imajı sorunları olan bireylerin sosyal medya platformlarını, imaj düzenleme ve iyileştirme seçeneklerini kullanarak, benliklerini başkalarına sunmanın uygun bir yolunu buldukları sonucuna varmışlardır. Bu biçimde kimi insanlar gerçek görüntülerinin bazı kısımlarını sadece arzu ettikleri yönleri ortaya çıkarmak için gizleyebilmektedirler. Bu, bireylerin sosyal medyadaki etkileşimleri, izlenimleri ve benliklerini sunmayı yönetme yeteneklerini geliştirebildiklerini göstermektedir. Aynı biçimde bireyler, kimliklerine ne eklemek istediklerini de çevrimiçi olarak kontrol edebilektedirler.

Sosyal medya platformu katılımı, bilgilerin ifşa edilmesiyle yakından bağlantılıdır. İzlenimleri yönetmek için kullanıcılar arasında belirlenen arzuyu genişleten sosyal medya siteleri, oyuncularını kendi deneyimlerini bildirmeye, fotoğraflarını yüklemeye ve mevcut kamusal alanlarda haberleri paylaşmaya teşvik etmektedir. Facebook'un 2020 raporu, fotoğraflar, haber güncellemeleri ve diğerleri de dahil olmak üzere milyonlarca içeriğin Facebook'ta günlük olarak paylaşıldığını göstermektedir. Sosyal ağ sitesi sağlayıcılarının kullanıc1 etkileşimleri için sunduğu desteği genişletmesi gerektiğini öne süren bir gözleme göre, sınırlı yeni malzeme arzı kullanıcıların bu sitelere ilgisinin kaybına yol açabilir ve sitelerin kullanımını olumsuz yönde etkileyebilir (Tsay-Vogel vd., 2018, s. 155). Bu gözlem, karşılıklı güncellemelerin, kullanıcıların aktif kalmalarını ve her zaman platformlara geri dönüşleri için motive edici olduğunu öne süren Hollenbaugh (2021) tarafından da doğrulanmıştır.

Çevirimiçi ortamlar için geliştirilen uygulamalar ile bu uygulamalara hızlı ve kolay erişim olanağı gittikçe büyüyen bir kullanıcı potansiyelini doğurmaktadır. Nitekim yapılan araştırmalar sosyal medya kullanıcılarının, sosyal medyayı bir zorunluluk olarak görmedikleri halde sosyal medya hesaplarına sahip olduklarını göstermektedir (Çavuşoğlu, 2020). Bu durumda, sosyal medya ortamları kullanıcılar tarafinda bir kamusal alan olarak görülmese de gerçek dünyadaki sosyalleşmenin bir yansıması olarak bu alana dahil olduklarını söylemek 
mümkündür. Sosyal medya kullanıcıları iletişim kurmaktan ve kendilerini farklı kesimlere sunmaktan hoşlanırlarken, bazıları da bilgi ifşası konusunda ihtiyatlı bir tutum geliştirmişlerdir. Çünkü kullanıcı mahremiyetine yönelik tehditler hakkında kullanıcı farkındalı̆̆ını artıran şüpheli bilgi işleme uygulamalarının yanı sıra mahremiyetle ilgili skandallarda da bir artış söz konusudur.

Günümüzde sitelerin çoğu, kullanıcılar arasında gizlilik ve mahremiyet konusunda endişe uyandıran özelliklere sahiptir. Sosyal ağ siteleri, kullanıcının kendini tanıtmasına yardımcı olan 'Hakkımda' (About Me) adı verilen önemli bir öğeye sahiptir. Bu öğe altında, yaş, cinsiyet, medeni durum, etnik köken, aile bilgileri, cinsel yönelim, meslek, eğitim gibi kişisel bilgiler gösterilebilir (Solmaz, 2017). İyimser bir bakış açısıyla bu tür özellikler, bir kişinin sosyal platformlardaki izlenimini, onları kamuya veya takipçilerine tanıtan bir açıklama eklemek için yönetmenin klasik bir yolunu sağlar. Bununla birlikte, Yang ve arkadaşları (2018), bazı kullanıcıların sosyal ağ site hesaplarının "hakkımda" bölümüne sahip olmadığını ve bu seçeneğe sahip bazılarının ise sadece iki veya daha az cümle içeren bir görünüme sahip olduklarını vurgulamaktadırlar. 'Hakkımda' bölümü, kişinin kendisini izleyicilerine sunmak için kendi yaptığı tanımlamaları içerse de, kimi internet kullanıcılarının, profillerine ekleyebilecekleri bilgilerin gizliliği konusunda yine de kendilerini güvende hissettiklerini söylemek pek mümkün görünmüyor.

Daha önce de değinildiği üzere, sosyal ağ siteleri, görünmez ve çok sayıda izleyici ile de karakterize edilmektedir. Siyasi ve dini mensubiyet, cinsel yönelim ve yaş grupları dahil olmak üzere kişilerin profillerine ilişkin bilgilere erişmek mümkünken, bazı kullanıcıların ise belirli bir kitleye ve belirli bilgilere erişmesi veya bunları sunması engellenmektedir (Boyd, 2011). Buradaki durumun, sosyal paylaşım sitelerinde benliği sunmak ile bu platformlarda geniş bir mahremiyet elde etmek arasındaki gerilimin devam ediyor olduğuna işaret ettiği söylenebilir. Sonuç olarak, bazı kullanıcılar, engellendikleri siteleri ziyaret etme konusunda güvenlerini yitirebilirler veya benliklerini sunma arzusunu devam ettirmek için çeşitli manevralar yapmanın yollarını bulabilirler. Bu nedenle çoğu internet iletişim platformunda anonimlikten yararlanılsa da, benliği sunmanın mahremiyetini veya gizliliğini etkileyen bazı öğeler, bireysel ve toplumsal ilişkilere/etkileşimlere zarar verebilmektedir.

\section{Sosyal Ağlarda Benlik Sunumu İçin Kullanılan Stratejiler ve Taktikler}

Benliği ideal bir kimlik kurgusunu tatmin edecek biçimde ortaya koyma ihtiyacı, bu hedefe ulaşmanın yollarını bulmak için itici bir güç haline geldi. Bu kısmen, sosyal ağ sitelerinin çevrimiçi izlenimleri yönetmesini sağlayanlar tarafından desteklenmektedir. Mevcut kullanıcılar sosyal ăg forumlarında kendilerini tanıtırken ve izlenimleri yönetirken çeşitli taktik ve stratejiler kullanırlar. Bazı çalışmalar, demografik özellikleri, teknolojiyi, gizlilik kullanım taktiklerini ve sosyal medya platformlarında benliklerini sunma stratejilerini analiz ederek bu tür stratejileri tartışmıştır.

Övgü ve yakarış stratejisi, 'benliği' sevilebilir kılarak hedefleri etkilemeyi içerir. Olumlu bir izlenim yaratmak, benliği çevrimiçi olarak sunmanın ana hedefidir; bu nedenle, kendileri hakkında doğru gördükleri biçimlerde geri bildirim almak için mesajlar gönderirler. Goffman'a göre, bireyler etkinliklerine kendi çıkarlarına olan bir izlenimi başkalarına iletmek için girerler: "etkileşimin devam ettirilebilmesi için yeterli uyumu sağlamak, aldatmak, başından savmak, akıl karıştırmak, yanlış yönlendirmek, karşısına almak veya hakaret etmek isteyebilir. Kişinin aklındaki amaç ya da bu amaca sahip olma sebebi ne olursa olsun, diğer insanların kendisine tepkilerini, özellikle de kendisine nasıl davranacaklarının denetimini elinde tutmak kendi çıkarına olacaktır" (Goffman, 2009, s. 17). İletişim teknolojileri, kullanıcıların profillerinde özel bilgileri paylaşmalarına olanak tanır, bu da izleyicilerin yorum eklemesine ve bunları okumalarına olanak sağlar (Ezzat, 2020). Bu strateji, farklı kesimlerin dikkatini çekmek isteyen kişiler için işler. Özellikle, Facebook, Instagram ve Twitter gibi sosyal ağ site kullanıcıları, oluşturulan izlenimlere tepkilerini belirterek yaklaşımlarını sıklıkla 
değiştirmektedirler. Örneğin, duvar güncellemeleri, genel duvar gönderileri ve özel mesajlar iletmek gibi çeşitlenen 'benlik' sunumları için çeşitli yollar kullanırlar. Bu strateji hakkında literatür, icracının izleyicilerin olumlu veya olumsuz tepkilerini üreten duyguları keşfetmek için içerik seçimine dikkat çekmektedir.

Benliği sunarken sosyal ağlarda kullanılan bir başka taktik ise, kişinin farklı hedef kitleler arasında kabul edilebilir olduğunu düşündüğü bilgileri yayınlamaktır. Lankton, McKnight ve Tripp (2017), sosyal medya kullanıcılarının 'benliği' sunarken, istenen izlenimi oluşturma ve diğer insanların onlar hakkındaki görüşlerini yönetme ihtiyacı ile izlenim motivasyonu oluşturma gibi iki ana hedefin olduğuna işaret etmektedirler. Ancak sosyal medya izleyicileri çeşitlilik gösterdiğinden bu hedeflere ulaşmak için doğru kitleyi seçmek kolay değildir. Kullanıcılar, bu hedeflere ulaşmak için en iyi ve en etkili stratejilere yönelme eğilimindedirler. Bu arada, Goffman'ın istenmeyen izlenim düşüncesi (unintended impression), olumlu bir izlenim yaratmaya uygun olmayan bazı yüzeysel mesajlar kullanıldığında ortaya çıkar (Beames vd., 2021). Chen (2019), olumlu izlenim oluşturma çabasında, bireylerin itibarlarını zedelemeyen veya hedefe ya da arkadaş grubuna yönelik saldırgan olmayan iyi niyetli bilgiler yayınladığını belirtiyor. Kullanıcılar olumlu izlenim oluşturabilmek için pratik olarak, profil sayfaları oluşturabilir, görüntüler veya farklılaşan içerikler kullanabilir, durumlarnı güncelleyebilir, başkalarının durumları hakkında yorum yapabilir ve farklı özellikler kullanarak diğerlerinin yanı sıra kamuya açık olarak bireylerle iletişim kurabilirler. Dolayısıyla literatür, kullanıcıların iki yönlü (izleyiciler ve kullanıcılar) işleyen benlik sunum hedeflerine ulaşmak için ağlarına daha az bilgi ifşa etme taktiğini uyguladıkları sonucuna varıyor.

Ayrıca, kendini çevrimiçi sunarken gerçek benliğin bazı kısımlarını gizlemek sosyal ağlarda yaygın bir eğilimdir. Genel olarak, internet ve sosyal ağ siteleri, abonelerine kendi aralarında ve izleyicileri arasında bir mesafe sunabilir; bu, çevrimdışı benliklerinin özelliklerini gizleme yeteneğini artıran fiziksel bir mesafedir (Selim, Long ve Vignoles, 2014). Hollenbaugh (2019), Facebook kullanıcılarını araştırarak insanların siteyi popüler olmak için kullandıklarını ve kendilerini geniş kitlelere arzu ettikleri biçimde sunmalarına olanak tanıyarak popüler olma eğilimini güçlendirdiğini buldu. Selim ve arkadaşları ise (2014), kullanıcıların internette benlik temsili konusunun özgünlüğü sorununu ele almıştır. Bu araştırmaya göre kullanıcılar, benlik sunumunda istenilen niteliklerini vurgularlarken veya abartırlarken, istenmeyen yönlerini gizleyerek benlik/kimlik kurgularında uyarlamalar yaptıklarını bulgulamışıı (Selim vd., 2014, s. 86). Nihayetinde, Goffman'ın kuramlaştırması, arzu edilen çevrimiçi kişilikleri oluşturmak için seçici benlik temsilinin nasıl kullanıldığını anlamanın bir yolu olarak çevrimiçi kimliğe ve onun analizine uygulanabilmektedir.

Kellner (2019) gibi kültürel çalışmalar yapan araştırmacılar, modern İngiltere'de moda ve kimliğin benliği ortaya koymada önemli bir rol oynadığını vurgulanmaktadır. Kellner, modanın bireylere arzu edilen kimlikleri inşa etmek ve kimlik krizleriyle yüzleşmek için uygun modeller ve malzemeler sağladığını belirtiyor (Kellner, 2019, s. 263). Moda, insanların kendilerini nasıl algilamak veya kabul edilmek istediklerini belirlemelerine ve betimlemelerine yardımcı olur. Sosyal medyanın daha görsel bir içeriğe ve etkileşimli katılıma evrilmesi, esas olarak video ve fotoğraf paylaşımının yaygınlık kazanmasından kaynaklanmaktadır. Örneğin, Harkin, Yates, Riach, Clowes, Cole ve Cummings (2021), çevrimiçi marka inşası için sosyal medyayı bir pazarlama aracı olarak kullanan sporcuların büyük bir marka sadakati sağlayabildiklerini ortaya koymuşlardır. Sporcular, birden fazla anlam ve amaç taşıyan moda seçenekleri aracılığıyla görüntüleri, metinleri, beğenileri ve yorumları paylaşmaktadırlar. Çevrimiçi kullanıcılar, tarz, giyim, makyaj ve imaj gibi moda seçenekleri sunarak benlik sunumlarında arzu ettikleri kimliklerini üretirler. Bu nedenle günümüzde medya kültürü, davranış, görünüm ve tarz için modeller sunarak sosyal medyada benlik sunma stratejilerinin oldukça etkili bir kaynağı haline gelmiştir. 


\section{Sosyal Ağlarda Gerçek Benlik Karşısında İdeal Benlik}

Sosyal ağ siteleri ve internet, insanların yaşamlarının gelişen dostluklar, ilişkiler, egzotik partiler veya tatiller, fotojenik, güzel, yapılı bedenler, yüzler ve sağlıklı yemeklerden oluştuğu yapay bir dünya olarak görülebilir. $\mathrm{Bu}$, internette mahremiyeti ve benliği idealize edilmiş bir biçimde sunmaya yönelik kitleler karşısındaki mevcut arzuyu tatmin etmektedir (Choi ve Sung, 2018). FaceTune ve Snapchat gibi çeşitli platformlar ve uygulamalar, kullanıcılara cilt tonlarından fiziksel niteliklerine ve biçimlerine kadar kendileriyle ilgili herşeyi değiştirme seçenekleri ve izni vermektedir. Hollenbaugh'un (2021) kendi kendini idealleştirme (self-idealization) perspektifine göre, benliğin sosyal medyadaki ifadesi abartılı, aşırı idealize edilmiş ve gerçek dışıdır. Bu perspektif, sosyal medyada mahremiyet ve benliğin sunumu ile sosyal ve kişisel temasları etkileyen ve kullanıcıların yanılsamaya dayalı yaşamlar sürmesini sağlayan gerçeklik arasındaki gerilimi vurgular. Bu noktada, sosyal medya ve internette benliğin ve mahremiyetin gerçek ve ideal sunumu arasındaki fark ve gerilime biraz daha yakından bakmakta yarar var.

Uzun zamandır araştırmalar, internette ideal benlik sunumunu kişilik açısından gerçek benlik ile karşılaştırmaya çalışmaktadır. Bu çalışmalar dikkat çekici ancak çelişkili bulgular sunmaktadır. Bu çerçevede Birnholtz, Burke ve Steele (2017), kullanıcıların çevrimiçi profilleri aracılığıla arzu edilen benlik sunumuna uygun olduğunu düşündükleri kişilik özelliklerine kavuşmayı umduklarını bulguladılar. Selim, Scott ve Kaye ise (2021), sosyal ağ sitesi katılımcılarının, gerçek kişiliklerini telafi etmek veya onlardan kaçınmak yerine, çevrimiçi sunumlarında çevrimdışı kişiliklerini genişlettiklerini tespit etmişlerdir. Selim ve arkadaşları (2021), uyumluluk, nevrotiklik ve dişa dönüklük özelliklerinin, kişinin gerçek benliğini ifade etme eğilimleriyle pozitif olarak bağlantılı olduğunu göstermişlerdir. Bu, Facebook'taki çoğu kullanıcının kendi idealleştirilmiş kişilikleri yerine gerçek kişiliklerini yansıtan profillere sahip olduğuna işaret ederken, çalışma bu eğilimin Instagram kullanıcıları ile olan farklılıklarını da vurgulamıştır. Facebook'ta insanlar gerçek isimlerini kullanmakta, oldukça kamusal bir alanda birbirleriyle etkileşime girmekte ve profilleri izlenebilir çevrimiçi sosyal günlükleri bile içerebilmektedir. Facebook'un tersine, Instagram ise ilişkiler kurmak ve sürdürmekten ziyade kendini tanıtma ve sunum odaklıdır. Instagram gibi sosyal ağlardaki kullanıcılar, kendilerini idealize edilmiş "benlik" biçimleriyle görsel olarak sunmaya daha fazla ilgi göstermektedirler. Bunu destekler biçimde Özkan (2020), Instagram fenomenlerinin, ön plana çıkma kaygısı ile kendilerini ve yaşantılarını sunarak idealize benlik sunumu sergiledikleri ve bu yolla çok sayıda takipçi edinip marka işbirlikleri sayesinde gelir elde ettikleri sonucuna ulaşmıştır (Özkan, 2020, s. 85).

Bazı çevrimiçi platformlar, özellikle Instagram, kullanıcıların kendilerini çekici biçimlerde gösterme baskısının artması nedeniyle görüntü paylaşma ve düzenleme etrafinda işlemektedir. Harkin ve arkadaşları (2021) çevrimiçi kullanıcıların, sosyal güvensizliklerini gidermek için neredeyse aldatıcı çeşitli alışkanlıklara düşkün olduklarını tespit etmişlerdir. Bunu, onları çekici gösteren veya profillerine fotoğraf çekmeden önce, çekim sırasında veya sonrasında fotoğrafları manipüle eden görüntüleri düzenleyerek veya seçerek yapmaktadırlar. Instagram, görüntülerin değiştirilmesini kolaylaştıran dijital filtreler içermektedir. Ayrıca, dijital 'kozmetik cerrahiye' ve böylelikle dijital görsellerin değiştirilmesine olanak tanıan Photoshop taklidi uygulamalar da bulunmaktadır (Dumas, Smith, Davis ve Giulietti, 2017, s. 4). Görsellerin geniş kitlelere sunulduğu çevrimiçi dünyada var olma olasılığının artması nedeniyle, kullanıcılar görsel aldatmalara dahil olmaya istekli oluyorlar. Dolayısıyla, bu çalışmalar açıkça göstermektedir ki, benliği sosyal medyada sunarken, gerçek veya ideal kimlikleri kullanma motivasyonları, platformun amacına ve uygun izlenimler yaratma arzusuna bağlı olarak değişkenlik gösterebilmektedir.

Sembolik etkileşimci kuram çerçevesinde (Carter ve Montes Alvarado, 2019), çevrimiçi sosyal etkileşimler anlam yaratan ve anlamlı eylemlerdir. Bu çerçeve doğrultusunda, Carter ve Montes Alvarado (2019), sembolik etkileşimlerdeki sosyal aktörlerin nasıl çevrimdış1 
kişiliklerinden farklı bir dijital benlik inşa ettiğini ele almaktadırlar. Sosyal medya platformları, kullanıcılarına, belirli özelliklerin paylaşıldığı ortamdaki aktörlere, iletiler kullanarak ilişkiler kurmalarını sağlayan bir güç sunar. Ancak yine de bireysel olarak tanışmamışlar veya sık sık görüşmemişlerdir (Bange, Järventie-Thesleff ve Tienari, 2020). Bange ve arkadaşlarına göre (2020), sosyal medyanın erişilebilirliği ‘benlik' etkinliklerinin sunumunda kayda değer etkilere sahiptir. Goffman'ın bakış açısını takip ederek söylenirse söz konusu platformlar, aktörlerin dijital kişiliklerini sergiledikleri yeni "sahne önü” arenaları kurarlar ve bu arenalar çevrim dışı benliklerinden pek çok biçimde sapabilir veya onları maskeleyebilir (Bange vd., 2020, s. 32). $\mathrm{Bu}$ platformlar, özel (sahne arkası) ve kamusal (sahne önü) mevcut geleneksel sinırları bulanıklaştırarak, çok sayıda izleyiciye ve çeşitli ortamlarda gerçek/özel benliklerinin kamuya açık dijital versiyonlarını göstermelerini sağlar (Bange vd., 2020, s. 33). Örneğin Ezzat'ın araştırmasına göre, kimi kadın aktörler kendilerini seksi, güzel, cana yakın, modaya uyan ve arkadaş canlısı olarak ve çevrimdışı benlikleriyle çelişen çevrimiçi bir imajı sunmaya takıntılıdırlar (Ezzat, 2020). Anılan araştırma, gerçekte kişinin davranış1 ve kişiliği ile çelişen imajlar/kimlikler yaratma arzusunun neden olduğu benlik sunum paradoksuna vurgu yapmakta ve bu da gerçeklik yerine bir yanılsama yaşandığ $/$ deneyimlendiği gerçeğini ortaya koymaktadır.

İzleyici ile oyuncu arasındaki mesafe, çevrimiçi benlik sunumunda gerçek ile ideal arasındaki ikilemi ve gerilimi vurgulamada büyük öneme sahiptir. Wright (2017) sosyal medya sunum olanaklarını Erikson'un bireylerin sonuçlara bakmaksızın deneyebilecekleri ve kimlik geliştirmede önemli bir aşama olan psiko-sosyal moratoryum durumu ile ilişkilendirmektedir. Dramaturjik kimlik kuramına göre, çevrimiçi ortamda oyuncular ile izleyiciler arasındaki mesafe, oyuncuyu engelleyebileceği için kimliklerin keşfedilmesini kolaylaştırır. Aslında bu, kimilerinin benliğin çevrimiçi sunumunun sağladığı olanaklardan yararlanırken, çevrimdışı dünyadaki insanların kimlikleri üzerinde somut sonuçlar doğurduğu anlamına gelir.

\section{Sonuç}

Sosyal medyada mahremiyetin ve benliğin sunulması, sosyal ve psikolojik gündelik yaşam üzerindeki yadsınamaz etkileri nedeniyle günümüz araştırmalarının üzerinde durduğu dikkat ve ilgi çekici bir konudur. Sosyal ağ platformları ve internet kullanıcıları genel olarak, insanların doğal bir özelliği olan kendilerini ve benliklerini başkalarına sunma arzusuna yataklık etmektedir. Ancak, bu arzuyu tatmin etmek amaciyla, insanların çevrimiçi ortamda ve çevrimdış1 dünyada gerçek benliklerini ortaya koyma biçimlerinde oluşan farkl1lıklar ve gerilimler söz konusudur. Kullanıcıların idealize edilmiş çevrimdışı benlik arzularını karşılamak için uyarladıkları görsel nitelikler söz konusudur. Konuya ilişkin literatür, daha geniş sosyal çevreler tarafindan kabul edilme ve takdir edilme ihtiyacından kaynaklanan bir izlenim yaratma niyetinin, bireyleri, özellikle çevrimiçi olmak üzere, 'benliği' en uygun biçimde sunmak için taktikler aramaya ittiğine işaret etmektedir. Metin boyunca da vurgulandığı üzere sosyal medya ağları, bu hedeflere ulaşmak için benlik ve mahremiyet sunumu bakımından zengin seçenekler sunmaktadır. Diğer insanların içerik eklemesine ve katkıda bulunmasına izin verilmesi, kişinin benlik sunumunu etkileyebilir ve bu da kişiyi psikolojik olarak etkileyen ve istenmeyen izlenimlere yol açabilir. Sosyal medya kullanıcıları, bundan kaçınmak için paylaştıkları içerik türünde seçici ve sınırlı olma eğilimindedirler. Bazıları istenilen belirli kişilik özelliklerini, fiziksel görünümlerini ve davranışlarını öne çıkarırken, istenmeyen diğer özelliklerini de gizlerler. $\mathrm{Bu}$, ideal ve gerçek benliği sunma paradoksuna işaret eder. İnsanlar, çevrimdış1 benliklerinden tamamen veya kısmen farklı ve fakat kabul edilebilir çevrimiçi kimlikler oluşturmak için çevrimiçi profillerini abartma veya kurgulama gibi aldatıcı davranışlara kapılırlar. $\mathrm{Bu}$ nedenle, insanlar 'idealize ettikleri yaşamlarını' sürdürürken yeni çevrimiçi kimliklerinin de 'aldatıcı keyfini' sürmektedirler. Bu çalışma, iletişim teknolojilerindeki gelişmeler ve bunların sağladığı firsatlar ve olanakları göz önünde bulundurarak, benliğin idealleştirilmesinin doğasını açıklamaya ve anlamaya yönelik sınırlı bir girişimdir. Mevcut çalışma, sosyal medya ve ağlarda sunulan 'benlikler' ile gerçeklikteki benliklerin sunumu arasındaki gerilimi vurgulayarak, sosyal medya ve ağlarının toplumsal ve kişisel etkileşimleri ve 
ilişkileri çoğunlukla olumsuz yönlerden etkilediği ve kullanıcıların büyük bir kısmının da yanılsamalara dayalı yaşamlar sürmesine neden olduğu sonucuna varmaktadır.

\section{Kaynakça}

Alvarez, K., \& Hua Chen, V. H. (2021). Cultivating community: Presentation of self among women game streamers in Singapore and the Philippines. Conference Paper, Proceedings of the 54th Hawaii International Conference on System Sciences, Hawaii.

Anderson, M., \& Jiang, J. (2018). Teens, friendships, and online groups. Pew Research. https://www.pewresearch.org/internet/2018/11/28/teens-friendships-and-online-groups/ (Erişim tarihi: 17.08.2021).

Bange, S., Järventie-Thesleff, R., \& Tienari, J. (2020). Boundaries, roles and identities in an online organization. Journal of Management Inquiry. 0 (00), 1-15. doi.org/10.1177/1056492620968913

Beames, S., Andkjær, S., \& Radmann, A. (2021). Alone with Goffman: Impression management and the TV series. Frontiers in Communication, 6, 1-9. doi.org/10.3389/fcomm.2021.676555

Birnholtz, J., Burke, M., \& Steele, A. (2017). Untagging on social media: Who untags, what do they untag, and why? Computers in Human Behavior, 69, 166-173. doi:10.1016/j.chb.2016.12.008

Boyd, D. (2008). Facebook's privacy train wreck: Exposure, invasion, and social convergence. Convergence, 14(1), 13-20.

Boyd, D. (2011). Social network sites as networked publics: Affordances, dynamics, and implications. Z. Papacharissi (Ed), A networked self: Identity, community, and culture on social network sites içinde (ss. 39-58). London: Routledge.

Bullingham, L., \& Vasconcelos, A. (2013). "The Presentation of Self in the Online World": Goffman and the study of online identities. Journal of Information Science, 39(1), 101-112. doi.org/10.1177/0165551512470051

Carter, M. J., \& Montes Alvarado, A. (2019). Symbolic interactionism as a methodological framework. P. Liamputtong (Ed), Handbook of Research Methods in Health Social Sciences içinde (ss. 169-187). New York: Springer. doi.org/10.1007/978-981-10-5251-4_62

Chen, A. (2019). From attachment to addiction: The mediating role of need satisfaction on social networking sites. Computers in Human Behavior, 98, 80-92. doi.org/10.1016/j.chb.2019.03.034

Choi, T. R., \& Sung, Y. (2018). Instagram versus Snapchat: Self-expression and privacy concern on social media. Telematics and Informatics, 35, 2289-2298. doi.org/10.1016/j.tele.2018.09.009

Çavuşoğlu, B. (2020). Yeni medya ve mahremiyet: İstanbul üniversitesi iletişsim fakültesi ögrrencilerinin facebook'a bakış açıları üzerine bir araştırma (Yayımlanmamış yüksek lisans tezi). İstanbul Üniversitesi, İstanbul.

DeVito, M. A., Birnholtz, J., \& Hancock, J.T. (2017). Platforms, people, and perception: Using affordances to understand self-presentation on social media. Proceedings of ACM CSCW'17 (ss. 740-754). Portland. doi.org/10.1145/2998181.2998192

Dumas, T., Smith, M. M., Davis, J. P., \& Giulietti, P. A. (2017). Lying or longing for likes? Narcissism, peer belonging, loneliness and normative versus deceptive like-seeking on Instagram in emerging adulthood. Computer Human Behavior, 71, 1-10. doi: 10.1016/j.chb.2017.01.037 
Evans, S. K., Pearce, K. E., Vitak, J., \& Treem, J.W. (2017). Explicating affordances: A conceptual framework for understanding affordances in communication research. Journal of Computer-Mediated Communication, 22(1), 35-52. doi.org/10.1111/jcc4.12180

Ezzat, H. (2020). The making of an Egyptian social media influencer. International Journal of Innovation, Creativity and Change, 14(11), 76-93. doi.org/10.53333/IJICC2013/141108

Facebook. What names are allowed on Facebook? (2020). Facebook. https://www.facebook.com/help/112146705538576/ (Erişim tarihi: 14.08.2021).

Franchina, V., \& Lo Coco, G. (2018). The influence of social media use on body image concerns. International Journal of Psychoanalysis and Education, X(1), 5-14.

Goffman, E. (1959). The Presentation of Self in Everyday Life. New York: The Overlook Press.

Goffman, E. (2009). Günlük Yaşamda Benliğin Sunumu (Barış Cezar, Çev.). İstanbul: Metis.

Gulmammadzada, U. ve Işıklı, Ş. (2020). Instagram'da benlik sunumu: Takipçi etkisi üzerine dramaturjik bir inceleme. AJIT-e: Bilişsim Teknolojileri Online Dergisi, 11(43), 74-104. doi: 10.5824/ajite.2020.04.004.x

Gül Ünlü, D., Kuş, O. ve Göksu, O. (2020). "Videolarda gerçek hayattaki gibi değilim, rol yapmaktayım": TikTok kullanıcılarının benlik performansları üzerine bir inceleme. Intermedia International E-journal, 7(12), 115- 128. doi: 10.21645/intermedia.2020.70

Harkin, B., Yates, A., Riach, M., Clowes, A., Cole, S. ve Cummings, C. (2021). "I want to see people's reactions to the selfies": A Lefebvrian analysis of the impact of social networking sites on physical, mental, and emotional functioning. Social Science Computer Review, 20(10), 1-21. doi.org/10.1177/0894439321994222

Harris, E., \& Bardey, A.C. (2019). Do Instagram profiles accurately portray personality? An investigation into idealized online self-Presentation. Frontiers Psychology, 10, 871. doi: 10.3389/fpsyg.2019.00871

Hearn, A. (2017). Verified: Self-presentation, identity management, and selfhood in the age of big data. Popular Communication, 15(2), 62-77. doi:10.1080/15405702.2016.1269909

Heston, M., \& Birnholtz, J. (2016). (In)visible cities: An exploration of social identity, anonymity, and location-based filtering on Yik Yak. iConference 2016 Proceedings, İllinois. doi.org/10.9776/16152

Hollenbaugh, E.E. (2019). Privacy management among social media natives: An exploratory study of Facebook and Snapchat. Social Media + Society, 5(3), 1-14. doi.org/10.1177/2056305119855144

Hollenbaugh, E.E. (2021). Self-Presentation in social media: Review and research opportunities. Review of Communication Research, 9, 80-98. doi.org/10.12840/ISSN.2255-4165.027

Jande, L. V., Ibrahim, N., Bahru, J., \& Aireen, N. (2020). The presentation of self and identity construction in virtual world: A case study of Avakin life. LSP International Journal, 7(2), 107-118. doi.org/10.11113/lspi.v7.15271

Jo, S., Yim, H.W., Lee, H., Lee, H.C., Choi, J. ve Baek, K. (2017). The internet game useelicited symptom screen proved to be a valid tool for adolescents aged 10-19 years. Acta Paediatrica, 107(3), 511-516. doi.org/10.1111/apa.14087

Jones, E. E., \& Pittman, T.S. (1982). Toward a general theory of strategic self-presentation. J. Suls (Ed), Psychological Perspectives on the Self içinde (ss. 231-262). Hillsdale, NJ: Lawrence Erlbaum.

Kellner, D. (2019). Media Culture. Cultural studies, identity and politics between the modern and the postmodern. London: Routledge. 
Lankton, N. K., McKnight, D. H., \& Tripp, J. F. (2017). Facebook privacy management strategies: A cluster analysis of user privacy behaviors. Computers in Human Behavior, 76, 149-163. doi.org/10.1016/j.chb.2017.07.015

Leary, M. R., \& Kowalski, R.M. (1990). Impression management: A literature review and twocomponent model. Psychological Bulletin, 107(1), 34-47. doi.org/10.1037/00332909.107.1.34

Morelock, J., \& Narita, F. Z. (2018). Public sphere and world-system: Theorizing populism at the margins. J. Morelock (Ed), Critical Theory and Authoritarian Populism içinde (ss. 135153). London: University of Westminster Press.

Muñoz-Rodríguez, J. M., Hernández-Serrano, M. J., \& Tabernero, C. (2020). Digital identity levels in older learners: A new focus for sustainable lifelong education and inclusion. Sustainability, 12(24), 10657. doi.org/10.3390/su122410657

Nova, F. F., DeVito, M. A., Saha, P., Rashid, K. S., Roy Turzo, S., Afrin, S., \& Guha, S. (2021). "Facebook promotes more harassment". Proceedings of the ACM on Human-Computer Interaction, 5(CSCW1), 1-35. doi.org/10.1145/3449231

Omori, K. (2014). Cultural differences in self-presentation on social networking sites: A crosscultural comparison between American and Japanese college students. International Journal of Interactive Communication Systems and Technologies 4(1):47-60. doi:10.4018/ijicst.2014010104

Özkan, K. D. (2021). Küreselleşme, sosyal ağlar ve gözetim toplumu bağlamında mahremiyet sorunları: Instagram içerik analizi. Akademi Sosyal Bilimler Dergisi, 8(22), 69-88. doi: 10.34189/asbd.8.22.004

Reinikainen, H., Tan, T. M., Luoma-aho, V., \& Salo, J. (2021). Making and breaking relationships on social media: The impacts of brand and influencer betrayals. Technological Forecasting and Social Change, 171, 120990. doi.org/10.1016/j.techfore.2021.120990

Sá, M. J., Serpa, S., Ferreira, C. M., \& Santos, A.I. (2020). Social media centrality in identity (Re)construction in higher education. Journal of Educational and Social Research, 10(1), 11-22. doi.org/10.36941/jesr-2020-0002

Santoso, N. R., Nombrado, M., De Guzman, M. T., Yumul, S. D., \& Mariano, R. M. (2021). Teachers' professional identity construction on Facebook using the teacher-student interaction perspective. Jurnal Studi Komunikasi (Indonesian Journal of Communications Studies), 5(1-23). doi.org/10.25139/jsk.v5i1.2763

Schlenker, B. R. (1985). Identity and self-identification. B.R. Schlenker (Ed), The self and social life içinde (ss. 65-99). New York: McGraw-Hill

Selim, H. A., Long, K. M., \& Vignoles, V. L. (2014). Exploring Identity Motives in Twitter Usage in Saudi Arabia and the UK. B.K. Wiederhold ve G. Riva (Eds), Annual Review of Cybertherapy and Telemedicine Positive Change: Connecting the Virtual and the Real içinde (ss. 128-132). Amsterdam: IOS Press.

Selim, H. A., Scott, G. G., \& Kaye, L. K. (2021). A cross-cultural study to explore the differential impacts of online social capital on psychosocial outcomes. Computers in Human Behavior Reports, 3(1-10). doi.org/10.1016/j.chbr.2021.100087

Seo, J., Lee, C., Lee, Y., Bhang, S., \& Lee, D. (2021). The type of daily life stressors associated with social media use in adolescents with problematic internet/Smartphone use. Psychiatry Investigation, 18(3), 241-248. doi.org/10.30773/pi.2020.0060 
Serpa, S., \& Ferreira, C.M. (2018). Goffman's backstage revisited: Conceptual relevance in contemporary social interactions. International Journal of Social Science Studies, 6(10), 74. doi.org/10.11114/ijsss.v6i10.3659

Solmaz, O. (2017). The presentation of self in social networking sites: An introduction, theory and the current state of the scholarship. Electronic Journal of New Media, 5(1), 49-59. doi.org/10.17932/iau.ejnm.25480200.2021/ejnm_v5i1005

Tsay-Vogel, M., Shanahan, J., \& Signorielli, N. (2018). Social media cultivating perceptions of privacy: A 5-year analysis of privacy attitudes and self-disclosure behaviors among Facebook users. New Media ve Society, 20 (1), 141-161. doi.org/10.1177/1461444816660731

Wright, M. F. (Ed.). (2017). Identity, Sexuality, and Relationships among Emerging Adults in the Digital Age. Pennsylvania: IGI Global.

Yang, M., Cao, C., \& Liao, H. (2018). Social media privacy concerns and self-presentation. International Joint Conference on Information, Media and Engineering (ICIME), Osaka, Japan.

Yıldız, İ. (2021). Sosyal medya ve mahremiyet sorunsalı: Panoptikondan süperpanoptikona mahremiyetin dönüşümü. Abant Kültürel Araşttrmalar Dergisi, 6(11), 122-132.

\section{ETİK ve BİLIMSEL İLKELER SORUMLULUK BEYANI}

$\mathrm{Bu}$ çalışmanın tüm hazırlanma süreçlerinde etik kurallara ve bilimsel atıf gösterme ilkelerine riayet edildiğini yazar(lar) beyan eder. Aksi bir durumun tespiti halinde Afyon Kocatepe Üniversitesi Sosyal Bilimler Dergisi'nin hiçbir sorumluluğu olmayıp, tüm sorumluluk makale yazarlarına aittir.

\section{ARAȘTIRMACILARIN MAKALEYE KATKI ORANI BEYANI}

1. yazar katkı oranı : \% 80

2. yazar katkı oranı : \% 20 